UDC 811.111

DOI: $10.17223 / 24109266 / 6 / 4$

\title{
"FIVE TO ONE. ONE IN FIVE": THE NUMBER IMAGES \\ IN THE LANGUAGE PICTURE OF THE WORLD OF JIM MORRISON
}

\author{
B.Ya. Sharifullin \\ Lesosibirsk pedagogical Institute, Branch of Siberian Federal University (Lesosibirsk, Russia). \\ E-mail: borshariff@gmail.com \\ Yeah, I'm proud to be a part of this number \\ Jim Morrison, "Soft Parade"
}

\begin{abstract}
In the article the number images are considered, as one of the key fragments of the language picture of the world of American poet and musician Jim Morrison. The symbolism of numbers, which is important for all lingual cultures, in the poetics of Jim Morrison is manifested in a special way, because of his specific perception of the world caused by childhood experiences. In the Jim Morrison's linguistic picture of the world the elements of European (Antic, Germanic, Celtic) culture and culture of North American Indians are invented. Jim Morrison has created also his own cultural code, American one, more exactly, a code of California, and the appropriate poetics of myths, that is reflected in his poetic texts. Therefore, the number images in the lyrics by Jim Morrison reflect all these cultural codes. For example, the using of the numeral four dates back to native American Indian traditions, and the numeral seven - to European one. The symbolism of the number "five" combines several cultural and mythological and poetic traditions all at once. In the article the most interesting cases of inclusion of some of the numerals in the lyrics are presented. English quotations from the songs are accompanied by Russian translations made by the author.
\end{abstract}

Keywords: language picture of world; cognitive and typological reconstruction; numeral; symbolism of number; Jim Morrison; The Doors.

\section{Introduction}

One of the most important components of the language picture of the world (LPW) in any nation and in any language is those fragment of knowledge about the world (real, mythological, esoteric), in which there is

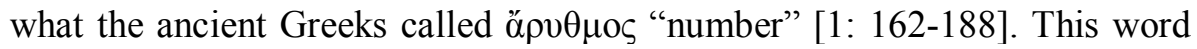
gave our arithmetic, literally "the art of numbersћ". With a Greek root associated also the word rhythm $(\rho v \theta \mu \rho)$ ), i.e. the ancient Greeks associated the rhythm of the Cosmos (ordered Universe) with the number, alias "Order".

The numbers in mythopoetic systems are one of the best-known classes of signs, focused on qualitative and quantitative assessment, it is a special numeric code, which describes the world and the man.

You must keep in mind that the symbolism of numbers in mythological beliefs is not universal but the regional phenomenon. When in the West 
Eurasia the number "three" or "seven" is dominated by, in Japan - "eight", in North America "four" and "five", in the East of Central America and Northern Colombia - "nine", etc. By the way, South American monsters have two heads instead of three.

In the poetics of myths of Jim Morrison, the famous poet and frontman of the American band "The Doors", "number" occupies a more important place than in LPW of "The Beatles", which is understandable, taking into consideration the particular mythopoetic perception of the world by Morrison.

The purpose of this article is to analyze the numerals in the lyrics of Jim Morrison in terms of their mythopoetic significance.

\section{The research methods}

The main research method in this article is a semantic-mythopoetic interpretation of textual material. The comparative textual analysis and methodology of translation and interpretation of the text are also used.

\section{The investigation}

The names of numbers themselves, in fact, are quite a lot in the texts of "The Doors", if we keep in mind only individual tokens, but the significance of them is high. The number line built as following: 1, 2, 3, 4, 5, 6, 7, $8,9,10,16,20,21,22,30,32,40,100,1000,28000,1000000,21$ lexemes at all. In the article, of course, it's impossible to consider all numerals in all their inclusions in the text, and therefore we confine ourselves to the most interesting cases.

\section{1}

One is a numeral not especially interesting, taking into consideration its often pronominal using, i.e. in the sense of "a, one": "there lived a man...". There are other enumerative meanings, for example, "one of some set", as in the song "Curses, Invocations" from the album "An American Prayer":

Weird bate-headed mongrels

I keep expecting one of you to rise.

Here is an example of using the lexeme one in its literal meaning of the numeral denoting the number "one":

Your brain seems bruised with numb surprise

Still one place to go.

2

The number "two" always has dual meanings in a variety of languages and linguistic cultures. It is a known fact and to confirm its with some links to Internet resources makes no sense. Just look at any "Mythological dic- 
tionary" or "Dictionary of symbols", and so on. Here the problems of "geminity" in history and literature lies, and the "dualism" of religious ideas and superstitions, etc.

Let's just refer to texts Morrison. In the song "Stoned Immaculate" (album "an American Prayer") numerals "one" and "two" occur in the same context:

One summer night, going to the pier

I ran into two young girls

The blonde one was called Freedom

The dark one, Enterprise.

Together with the corresponding number "five" number "two" is found in the song "Land Ho!" (see below, on the number "3") in the snippet, which is the rowers' old Maritime descant for the more rhythmic of the oars, inserted by Morrison in the text of his song:

If I get my hands on a number five,

Gonna skin that litlle girl alive.

If I get my hand on a number two,

Come back home and marry you, marry

You, marry you.

The number " 3 " at Morrison is presented only in one song, "Land Ho!" from the album "Morrison Hotel", although the number " 3 " by itself is mentioned in many religions and mythologies. So, in Christianity, the number is represented in the Holy Trinity, in Ancient Egypt family tree consisted of Isis, Osiris and Horus, in Hinduism the universe is ruled by Brahma (the Creator), Shiva (the Converter) and Vishnu (the Guardian) [2: 550].

In some interview, Jim noticed that he didn't like that number, it associates by him with the Trinity, and it causes him some kind of rejection. Perhaps this is due to children's and youth experiences (three children of his parents, rejection of Catholicism, with its cult of St. Trinity, etc.). "Trinity" pursued Jim up to his death: for example, "love triangle" (loved with Pamela Curson, Jim shortly before his death married another woman, but then he went along with Pamela to Paris).

Here's the snippet of the song:

Yea! I've got three ships and sixteen men,

A course for ports unread.

I'll stand at mast, let north winds blow

Till half of us are dead.

Land ho!

4

The number "four" encounters in a very interesting context of a rather complex compositions "Soft Parade" from the eponymous album of 1969: 
There's only four ways to get unraveled

One is to sleep and the other is travel, da da

One is a bandit up in the hills

One is to love your neighbor 'till

His wife gets home.

In the beginning of this article I mentioned that the North American Indians considered "4", also "5" as particularly sacredly significant. First, the cult of nature included the worship of the four elements: earth, fire, water, wind, each of which had its own personification. The Dakotas, for example, personified the Earth as the spirit of Tunkan etc.

Secondly, the cult of the four parts of the world. At the Indian tribes according to the four parts of the world the stocks were grouped. During the ritual gatherings they were located in a certain order, in four sectors of a circle, symbolizing the world construction [3].

Let's take a look at these Indian tetrads, how they fits the text of Jim Morrison, obviously, used the symbolism of the number "4" in its composition. So, the sleep, the travel, the robbery (war) and love are the four ways to get unraveled.

The sleep and the Earth? The war and the fire? The travel and the water? The love and the wind? It is quite possible. The sleep (not dreaming, he word sleep is related, by the way, with Russ. слепой) is a metaphor of death, and therefore, the image of the chthonic, i.e. connected with the earth as a ground.

The war and the fire are also connected. Why the bandit from the hills is associated with the war? I think that's understandable. The situation is similar to our Caucasus...

The travel and the water are related, at least in the sense that for mythopoetics and symbolic of Morrison, the water, the sea, the river is very significant [4]. And the sea, the river means swimming.

The love and the element of the wind are probably associated also. Love is also natural, but fickle as the wind. No wonder that in the Russian language about the woman is spoken "windy".

One more time we see the number "four" in at already mentioned song "Land Ho!":

This old man was graceful

With silver in his smile.

He smoked a briar pipe and

He walked four country miles.

American colloquial expression country mile means "the greater distance, the long road", which is obviously due to immeasurable distances in rural areas of the United States.

Lexeme five is presented in the song "Five to One" from album альбома "Waiting for the Sun" of 1968: 
Five to one, baby

One in five

No one here gets out alive, now

You get yours, baby

I'll get mine

Gonna make it, baby

If we try

The ratio of 5 to 1 , mentioned here, is still a matter of controversy: whether it is the ratio of whites to blacks in the $60 \mathrm{~s}$, whether of normal people to drug addicts, or people over the age of 25 and youth. In this song we meet also the word number, literally, "номер", as it translated often in Russian:

They got the guns

But we got the numbers

Gonna win, yeah

У них есть оружие, а у нас есть номера!

Мы должны победить!

However, all is not so simple: in the slang the word number (in singular and plural) has a whole set of other meanings, for example, "money". So, in the song of the Beatles "Carry That Weight" a line "You never give your number" is translated as "You never give me your money" in Russian. Such a translation is possible here.

But there are also other possibilities. For example, taking into consideration the often sexual context of many of the songs by Morrison, it is highly likely the slang meaning of the plural form the numbers as "male genitalia, specifically the testicles" (http://www.urbandictionary.com/define.php? term=number).

In favor of this version is the fact that during the recording of the song Jim sang, as always improvising, "And get fucked up", this sentence in the album version was thoroughly mixed by sound engineers (https://ru.wikipedia.org/wiki/Waiting_for_the_Sun).

In this context, I dare to make such an interpretation of a combination of five to one: the ratio of adult Americans ("fathers") to young people ("children"), which considered themselves Morrison and Pamela. Again a reflection of generational conflict and Jim's conflict with his parents (in the background of the "flower revolution" of the 60s: hippies, flower children). Among them, the "fathers", there are all sorts of rifles, pistols, but we, "children", have strong "balls", and of course, we will win! This is indicated with the previous line of the song:

The old get old

And the young get stronger

He line No one here gets out alive became later the name of the biography of Jim Morrison, written by John. Hopkins and D. Sugarman. 
In its direct numerical meaning "five" the word is used in the song "The Movie" from the album "An American Prayer":

The movie will begin in five moments

The mindless voice announced.

A special comment, in fact, is not required.

6

The number "six" we met only in the song "Angels and Sailors" from the album "An American Prayer":

Girls in garages, stripped

Out to get liquor and clothes

Half gallons of wine and six-packs of beer

It is, rather, not actually about six boxes, but about one box, which contains six cans or bottles of beer. So why there is a hyphen in the expression six-packs. A gallon is about two and a quarter liters.

The number "seven". Like they say in English, "Seven Is a Number in Magic" (there is a song of the group, in fact, the Dutch, "Shocking Blue", 1970). This is certainly true: in the linguistic cultures of many Nations, including European, this number is an important concept that has a very voluminous conceptual sphere. Enough, for example, to mention the "week" (seven-day week, each day was associated in ancient Babylon with the seven planets and their respective deities; in English, it is still available: Sunday "day of the Sun" Monday "day of the moon" Tuesday "day of Mars, the ancient German God Tiuz", Wednesday "day of Mercury and ancient Germanic God Wodan" etc.).

In the Bible, the number "7" is a human, there are seven deadly sins, seven virtues, seven sacraments. The same is in Russian LPW: how much sayings, superstitions, etc., associated with the number, "seven" are presented in it: семь пятниц на неделе, у семи нянек дитя без глазу, одним махом семерых убивахом, седьмая вода на киселе еtс.

But the Indians of America, as I wrote above, this number has no special value. But Jim Morrison reflects still more European cultural code: ancient, Christian, Germanic, Celtic. Therefore, in his poetics of myths the number "seven" is quite significant. This is manifested, first of all, in the song "Love Her Madly" from the album "L.A. Woman":

All your love is gone

So sing a lonely song

Of a deep blue dream

Seven horses seem to be on the mark

The Russian poet Konstantin Balmont wrote the poem "Seven horses", the modern Russian singer Vaenga performs the song of the same name? which is a metaphor for the seven-string guitar. The British rock group "Icicle Works" has a song "Seven Horses", as the American actor and singer 
Jonathan Rado too. So, the combination of seven horses is very "popular". The symbolism of both the number and the animal explains it, perhaps. Nikolai Gumilev, by the way, wrote the ballad "Five horses".

We meet the number "7" in the same context as the name of the animal, snake in the song "The End":

The snake is long, seven miles

Ride the snake... he's old, and his skin is cold.

The number " 7 " here is not accidental: in European folklore, including Russian, this numeral in combination with nouns denoting units of length, size, etc. parameters, is used to mean an unspecified but significant amount.

Cf. English seven-league, seven-mile strides, i.e. "very wide, long". Hence is the folklore image of the "seven-league boots", for example, in "Cinderella". The English mile is approximately equal to Russian not a metric unit of length, a versta. Cf. Russian proverb:

Семь верст до небес и все лесом - about a distant and difficult path to the goal.

За семь верст киселя хлебать - to go on a long and arduous journey and return with nothing.

Thus, the "seven-miled snake" is a very long great snake. In Slavic folklore, there is the image of the "snake of the seven heads" also, but this is a different story. A more complex example of the semantics of the number "7" in the song "Celebration of the Lizard", again associated with the snake (lizard):

For seven years I dwelt

In the loose palace of exile

Playing strange games

With the girls of the island.

The number "7" in this case, in combination with nouns denoting a certain period of time, also has folklore motivation, intertwined in the sense of "some time, often a long period". In other words, it's analogous to the using of the number " 7 " to indicate a long and difficult journey.

\section{8}

This number met in the song "Black Train Song" from album "Without a Safety Net (part of The Doors Box Set)":

Well, I woke up a morning

Got the eight ball on my mind

Why 8 balls, i.e. bullets? Obviously, this refers to the famous 8 -shooter revolver "Smith \& Wesson", especially popular in the era of the Wild West. In other words, the entire drum of the revolver released to the head.

9

Although in modern numerology, referring to mythological traditions, the number 9 is regarded as very significant, in the lyrics of "The Doors" the numeral nine is missing, and it is presented only in one poem by Jim 
Morrison, and not in symbolic, but in the ordinary meaning, just an indication of the actual time of the day:

I will be there

after 9:30 p.m.

("Wilderness", poems of 1965-1971).

10

The numeral ten we find in the song "Build Me a Woman" concert from the 1970 album "Absolutely Live":

Build me a woman,

Make her ten feet tall.

Don't make her worthless,

Don't make her small.

The song perfectly lies in the context of the relationship Morrison with women. It is interesting here that, in my opinion, Jim perhaps ironically used the image of a giant woman Nancy from the cult sci-Fi American film from 1958, directed by Nathan Yuran "Attack Of The 50-ft. Woman". Foot is an Anglo-American unit of length, approximately equal $30.5 \mathrm{~cm}$. The numeral fifty, apparently, was not included in the size of the string, and Jim replaced its with ten, thereby reducing the growth of its "women" in 5 times.

\section{3}

This number appears only in the title of a collection " 13 " of 1970 , according the number of hits, included in its contain.

\section{6}

The number 16 (sixteen) we find in the song "Black Train Song" (album "Without a Safety Net" (a part of "The Doors Box Set"):

Train-a-ride

Sixteen coaches long

Where there be no train

Took my baby, he's gone

Obviously computer and therefore funny translation I found on the website http://tekst-pesni-tut.ru/song/show/1712130/the-doors/tekst-pesni-iperevod-black-train-song/:

Поезд-a-ride

Шестнадиать соасhеs долго.

Там, где нет железнодорожного.

Взял мой ребенок, он ушел.

Other "normal" translation I did not find on the Internet, therefore, I propose my own:

Едем на поезде

Длиной в шестнадиать вагонов

Туда, где не будет никакого поезда.

Он забрал мою девушку, он ушел. 
With this translation, however, there are difficulties associated with a deixis: the combination he's gone has to do with some kind of an animate entity that "took my girl", but the meaning refers to the train. This noun is inanimate and would require the pronoun it.

My explanation is: obviously, this train at Morrison's is a living being and, most likely, associated with the Snake (visually it's clear, train like a snake crawls, bends, as it also consists of segments-cars), which is the key "hero" of some of his songs. In favor of this assumption is the use of verb to ride (remember the words ride a snake from the composition "The End"), as well as lexical and semantic parallelism: The snake is long, seven miles and Train-a-ride / Sixteen coaches long. 16 cars, of course, are not seven miles long, but who are them, the Americans, knows/...Perhaps Jim in the writing of this text had any allusion to the famous American song "The Sixteen Tons".

In general, this train-the snake took the hero's girl, because she rides a snake. The second example of the use of the numeral " 16 " is in the song "Land Ho!", I have already mentioned:

Yea! I've got three ships and sixteen men,

A course for ports unread.

I'll stand at mast, let north winds blow

Till half of us are dead.

Land ho!

A very interesting interpretation about "sixteen men" on a board of "nice old man" emerges here. The first thing that came to my mind when I first heard this song in his student years were the famous "Fifteen men on the dead man's chest", known in Russia by the movie "The Treasure Island". It was an old pirate song, and there, from time to time, these menwere killed - as at Morrison's in his song.

But in Jim's text there were "sixteen men", and the text "Fifteen men on the dead man's chest" is considered canonical, used by Stevenson in his novel.

Is it a Morrison's slip (which is possible too)? Or he did o purpose, under the influence of, for example, the already mentioned song "The Sixteen Tons"? And here's an interesting fact: modern Russian rapper from Novosibirsk Uncle Zhenya has a song "16 men on a dead man's chest". There, among a heap of Russian rap structures, there is the English text:

Sixteen men on a dead man's chest

and I've been drinkin' from a broken cup.

I think that this Uncle Zhenya, if he was familiar with the works of Morrison, showed his creative: he compiled "sixteen" with "dead man's chest". Anyway, the song "Land Ho!", of course, written in "pirate" style and "sixteen men" there are not accidental. 
20

This number is found in the song "Twentieth Century Fox" from the album "The Doors". I reviewed the playing character of the song title in accordance with the translation of the text itself, in the article about the Morrison's poetics, which is now being prepared for publication. In any case, the meaning of the numeral is obvious: "the twentieth century".

In a poem "L' America" (collection of "Wilderness", the poems 19651971) this numeral is also represented:

\section{L'America}

eyes like twenty

\section{L'America}

The combination eyes like twenty in one of Russian translation is given as “отличное зрение”. Better still: “глаза как в 20 лет”, i.e. young.

P. S. There is a rock band from Birmingham, Alabama, "Eyes like the 20", the title of which, as said Boyd Richie, one of its founders, was taken from this line of the poem by Jim Morrison. Here's their logo:

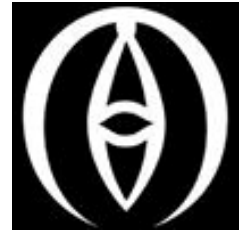

21

We met the number " 21 " in composition "Woman Is A Devil" in the collection "Essential Rarities" (1999):

Well she feel like dyin'

But she only only twenty-one

She not the only one alright,

Gonna save the whole world, alright.

21 years old is the age of majority in some countries, in the USA - in New York and Mississippi. In most countries, and States the legal age of majority is 18 years old, including also Russia.

\section{2}

This quite rare number for its significance, unlike "21", presented in the song "Who Do You Love?" (the album “Absolutely Live", 1970):

Tombstone head and graveyard mind,

Just twenty two and I don't mind dying.

Actually, this song was written by Ellas Mac Daniel, better known as Bo Diddly, but it was very in tune with the Jim's worldview, especially as it manifests the image of the snake (see the number " 40 ").

\section{0 and 32}

Generally it's rather badly with numbers from 30 to 40 in the lyrics of rock groups, British and American: I know only the Queen's “39". In the 
poems by Jim Morrison the number 30 is presented as the designation of minutes and 32 - as the room number in the hotel:

I am a guide to the labyrinth

Come \& see me

in the green hotel

Rm. 32

I will be there

after 9:30 p.m.

\section{0}

This number is found in the song "Who Do You Love?" from the live album 1970 "Absolutely Live":

I walked forty damned miles of barbed wire,

Cobra snake a-for a necktie,

Built new house by the roadside,

Made from rattlesnake hide.

Why just 40 miles? Perhaps Bo Diddley equated it with the 40 years, during which the prophet Moses led his people through the desert. In America there is such a lot of deserts, and the roads through them are often surrounded by barbed wire.

100

We find this numeral "hundred" in the quite rare Morrison's song "Hour For Magic" (from the album "An American Prayer"):

Give us trust in

The Night

Give of color hundred hues

a rich Mandala

for me \& you.

This is actually a poem from the same Jim's collection, not originally intended for singing. The mandala (Sanskrit मण्डल "circle drive") is a schematic sacral illustration or the construction of complex structures, symbolizing the Universe and used in Buddhist and Hindu religious practices [5].

\section{0}

The number thousand is presented, first of all, in the song "Love Her Madly" (album "L.A. Woman", 1971):

Don't ya love her as she's walkin' out the door

Like she did one thousand times before

It's interestingly, in English, as in Russian, the numerator thousand can refer to an indefinite, but a great set, i.e. she could do it ("to walk outside the door") much more than just a thousand times. It's embarrassing, really, that the word one indicates an exact numeric meaning: "one thousand". The sense of undefined, but a significant set is represented, rather, in the song "The Crystal Ship": 
The crystal ship is being filled

A thousand girls, a thousand thrills

A million ways to spend your time

When we get back, I'll drop a line

The same meaning of uncertain, but a great set of the objects is reflected in the following example:

When the true kings murders

Are allowed to roam free,

A thousand magicians arise in the land

Where are the feast we are promised?

("The Ghost Song")

\section{0}

In the poetry of Jim Morrison ("Wilderness", the poems 1965-1971) there is such a "non-standard" number:

I have a vision of America

Seen from the air

$28000 \mathrm{ft}$. \& going fast.

28000 feet are about 8.5 kilometers. It's completely normal height for passenger aircraft like "Boeing". But I allow to offer also such an interpretation, taking into consideration the quivering Jim's attitude to birds, especially the eagles. I have no proof, but if you imagine that Jim Morrison felt himself not only a snake, but an eagle too, he could metaphorically see America from the height of bird flight. There is evidence that the condors, for example, fly over the Andes at altitudes of up to 9000 miles.

\section{0}

In the song "The Crystal Ship", in the same verse, which I have already cited above, the numeral million is used too:

A million ways to spend your time

When we get back, I'll drop a line.

Of course, the number "a million", like "a thousand", does not denote the exact quantity: that is simply the expression of a great multitude, like the Russian "I've already told you a million times not to come home late!"

P.S. In the album of "The Doors" "Full Circle" there is a song "4 Billions Souls", but it was occurred after the death of Jim Morrison - 1972.

\section{Conclusion}

The article describes the numerical symbolism in the lyrics by Jim Morrison, which holds a prominent place in his language picture of the world. After analyzing not all, but the most interesting inclusions of numerals into Morrison's songs, in comparison with the possibilities of translation and interpretation in Russian binding, we concluded that the significance of numerical nominations in many of the songs by Morrison is quite high. In 
addition, the fact that Jim Morrison has created a world at the crossroads of European and North American Indian traditions is confirmed one more time.

\section{References}

1. Sharifullin, B.Ya. (2014) The Language Picture of the World of "The Beatles": The Cognitive and Typological Reconstruction. Saarbrucken: Lambert Academic Publishing. 216 p.

2. Ye.M. Meletinskiy (ed.) (1988) The Mythological Dictionary. Moscow: Sovetskaya entsiklopedia. $736 \mathrm{p}$.

3. Limarev, V.N. The Ancient Believes of the North American Peoples. [Online]. Available from: http://religion.limarevvn.ru/ind.htm.

4. Fevraleva, E.A. (2010) The Image of the Ship and the Sea (the Way) in LPW of Jim Morrison. Student and scientific-technical progress: proceedings of XLVIII International scientific conference of graduate and undergraduate students, 10-14 April 2010, Novosibirsk State University. Linguistics. Novosibirsk: NSU publishing house. pp. 74-75.

5. Toporov, V.N. (1992) Mandala. The Myths of People of the World. 2. Moscow: Nauka. pp. 100-102. 